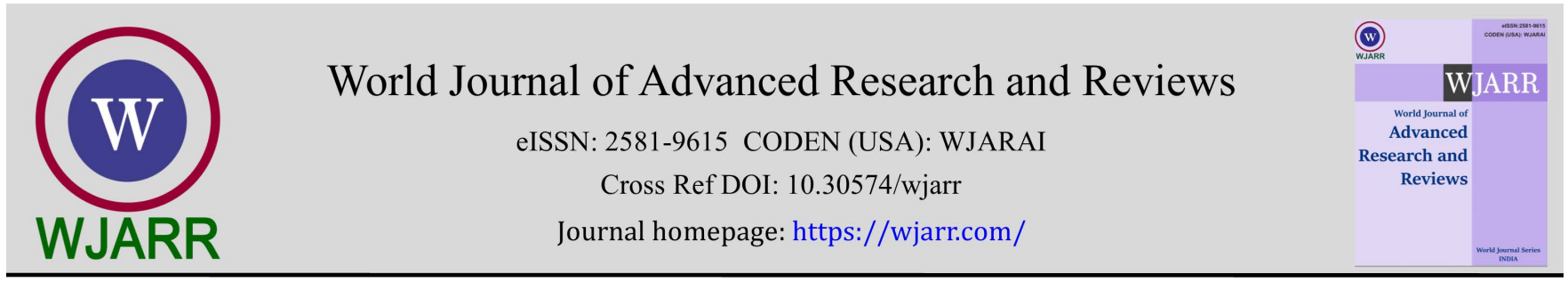

(RESEARCH ARTiClE)

\title{
Screening of microorganisms for hydrolyases with commercial potential
}

\author{
Jay N Patel, Fenil A Parmar and Vivek N Upasani * \\ Department of Microbiology, M. G. Science Institute, Ahmedabad -380009, Gujarat, India.
}

World Journal of Advanced Research and Reviews, 2022, 13(01), 092-101

Publication history: Received on 28 November 2021; revised on 01 January 2022; accepted on 03 January 2022

Article DOI: https://doi.org/10.30574/wjarr.2022.13.1.0751

\begin{abstract}
Advancement in green chemistry has increased the use of microbial hydrolyases in various industries and chemical processes because of high catalytic efficiency, specificity, cost-effectiveness and eco-friendly nature. Bioconversion of tannins such as tannic acid is achieved by tannin acyl hydrolase, also known as tannase. It converts tannic acid into glucose and gallic acid by catalyzing the hydrolysis of ester and depside linkages in tannic acid. Tyrosinase is monophenol and $O$-diphenol oxidase a copper containing enzyme catalyzes the oxidation of tyrosine and generates different types of pigment such as melanin. Xylanases hydrolyze xylan into its constituent sugar with the help of several debranching enzymes. Microbial strains isolated from various sources were screened for these hydrolyases: Bhavnagar marine salterns (Bacillus megaterium BVUC_01 and Bacillus licheniformis BVUCh_02); Okhamadhi marine salterns Aspergillus versicolor; Spoiled/infected pomegranate (Xenoacremonium falcatum, two strains PGF1 and PGF4, Bacillus velezensisPGF2 and Candida freyschussiiPGF3. The other laboratory maintained bacterial cultures namely, Bacillus subtilis, Pseudomonas aeruginosa, Staphylococcus aureus, Salmonella typhi were also used in this study. Asp. versicolor and Xen. falcatum (PGF1) produced all the three enzymes (tannase, tyrosinase and xylanase). B. licheniformis, B. megaterium, B. subtilis, B. velezensis produced tyrosinase and xylanase. Xen. falcatum (PGF4) and PGF2 produced tannase and xylanase. PGF3 produced tannase and tyrosinase. While, Bacillus megaterium and Salmonella typhi showed only tyrosinase activity. Candida freyschussii showed tannase activity. Staphylococcus aureus did not produce any of these enzymes.
\end{abstract}

Keywords: Bacillus velezensis; Xenoacremonium falcatum; Candida freyschussii; Tannase; Tyrosinase; Xylanase

\section{Introduction}

Enzymes are biocatalyst which catalyzes reaction with high catalytic efficiency and specificity. With advancement in green chemistry, the use of enzymes in various industries and chemical processes enormously increased because of its cost-effectiveness and eco-friendly nature $[1,2]$. Bioconversion of tannins such as tannic acid is achieved by tannin acyl hydrolase (TAH; EC 3.1.1.20), also known as tannase. It converts tannic acid into glucose and gallic acid by catalyzing the hydrolysis of ester and depside linkages in tannic acid [3, 4]. Tannin is a water soluble, phenolic compound with capability to precipitate proteins from solution [5]. It is widely present in plants which are used for human consumption $[5,6]$. Microbial tannase is more stable than plant and animal tannase, so microorganisms become most favored source of tannase [7]. Tannase have wide range of applications in various industries such as, food [8], cosmetics [9, 10], leather $[11,12]$, pharmaceutical $[13,14]$, animal feed and in treatment of waste waters $[15,16]$. Despite of its applications, there are very few report on its sources, throughout the world $[17,18]$. Tannins have toxic effect on microbes and inhibit their growth $[6,18]$. Tyrosinase is a monophenol and $O$-diphenol oxidase, copper containing enzyme which catalyzes oxidation of tyrosine and generates different types of pigment such as melanin. It is widely distributed among prokaryotes as well as eukaryotes [19]. The mode of action of tyrosinase is that, hydroxylation of its substrate (monophenol) to $O$-diphenol followed by oxidation of diphenol to $O$-quinones. In whole sequential process it requires

\footnotetext{
*Corresponding author: Vivek N Upasani

Department of Microbiology, M. G. Science Institute, Ahmedabad -380009, Gujarat, India..

Copyright $(2022$ Author(s) retain the copyright of this article. This article is published under the terms of the Creative Commons Attribution Liscense 4.0.
} 
molecular oxygen [20, 21, 22]. If substrate is tyrosine then, upon hydroxylation it will be converted into 3,4dihydroxyphenylalanine or DOPA, and upon oxidation of DOPA it is converted into dopaquinone followed by series of enzymatic and non-enzymatic reactions which ultimately results in production of melanin pigment [23]. In fungi, tyrosinase plays an important role in browning, pigmentation [24, 25], defense and virulence mechanism [26, 27], stability of spores [28] and also contributes in resistance to some radiation and extreme temperatures [29, 30]. Plant contains a variety of phenolic compounds which are oxidized by tyrosinase browning as a primary immune response during injury of tissues [31,32,33]. Tyrosinase is used for bioremediation of industrial waste waters and soil containing phenolic compounds as a common pollutant, which is toxic in nature and hazardous for human health $[33,34,35,36]$. Apart from this tyrosinase is widely used in pharmaceutical, food processing and cosmetic industries [19, 37, 38].Main components of lignocellulosic material are hemicellulose and cellulose [39, 40]. Hemicellulose consists of xylan, arabinan, mannan and galactan as major heteropolymers $[41,43]$. In higher plants about one third dry weight of hard wood hemicellulose contains xylan $[40,42,43]$. Xylanases hydrolyze xylan into its constituent sugar with the help of several debranching enzymes $[42,43,44]$. The biotechnological and industrial applications of xylanases have increased enormously in the recent years $[45,46,47]$. With the development in the use of these enzymes in biotechnology and other industries has led to increased demand for new sources of these enzymes. Therefore, the objective of this study was to screen microorganisms from various sources for the production of hydrolyases tannase, tyrosinase and xylanase.

\section{Methodology}

Microbial strain used in this study: Bacillus megaterium, Bacillus licheniformis, BVUC_01, BVUCh_02 isolated from Bhavnagar marine salterns [48]; Aspergillus versicolor isolated from Okhamadhi marine salterns [48];Xenoacremonium falcatum(two strains PGF1 and PGF4), Bacillus velezensis, Candida freyschussii, PGF2, PGF3, isolated from spoiled pomegranate [49]. Apart from this four bacterial strains - Bacillus subtilis, Pseudomonas aeruginosa, Salmonella typhi and Staphylococcus aureus were also used in this study.

\subsection{Screening for production of extracellular tannase, tyrosinase and xylanase enzymes}

Primary screening of the isolates for production of tannase, tyrosinase and xylanase was done by using plate assay method. For fungi $\mathrm{pH}$ of the medium was adjusted to 6.5-7.0, for bacteria $\mathrm{pH}$ of the medium was adjusted to 7.2-7.4.

\subsubsection{Screening for tannase production}

Screening of microbial cultures for production of tannase was done by using Tannic acid agar medium (TAA) containing (g/L): tannic acid, 10.0; $\mathrm{NaNo}_{3}, 3.0 ; \mathrm{KH}_{2} \mathrm{PO}_{4}, 1.0 ; \mathrm{MgSO}_{4} .7 \mathrm{H}_{2} 0,0.5 ; \mathrm{KCI} 0.5 ; \mathrm{FeSO}_{4} .7 \mathrm{H}_{2} \mathrm{O}, 0.01$; Agar-agar powder, 30.0 [52].

\subsubsection{Screening for tyrosinase production}

Tyrosinase activity of cultures was screened by using medium containing (g/L): Peptone, 5.0; Yeast Extract, 3.0; Ltyrosine, 5.0; Agar-agar powder, 20.0 [53].

\subsubsection{Screening for xylanase production}

Screening of cultures for production of xylanase was done by using media containing (g/L): (A) for bacteria: Xylan, 5.0; $\mathrm{MgSO}_{4} \cdot 7 \mathrm{H}_{2} \mathrm{O}, 0.05 ; \mathrm{NaCl}, 0.05 ; \mathrm{CaCl}_{2}, 0.01$; yeast extract, 0.2;peptone, 0.5; Agar-agar powder 20.0 [50]; (B) for fungi: Xylan, 5.0; $\mathrm{MgSO}_{4} \cdot 7 \mathrm{H}_{2} \mathrm{O}, 0.05 ; \mathrm{CaCl}_{2}, 0.05 ; \mathrm{NaNO}_{3}, 0.005 ; \mathrm{FeSO}_{4} \cdot 7 \mathrm{H}_{2} \mathrm{O}, 0.009 ; \mathrm{ZnSO}_{4}, 0.002 ; \mathrm{MnSO}_{4}, 0.012 ; \mathrm{KCl}, 0.23$; $\mathrm{KH}_{2} \mathrm{PO}_{4}, 0.23$; peptone, 2.0; Agar-agar powder 19.0g [40, 43].

The solid media were spot inoculated with the actively growing cultures and incubated as follows: bacterial cultures were incubated at $37^{\circ} \mathrm{C}$ for $24-48 \mathrm{hrs}$; while fungal cultures were incubated at room temperature $\left(20-25^{\circ} \mathrm{C}\right)$ for $48-72$ hrs.

After incubation tannase and tyrosinase activity was detected by color change. Formation of brown halos around microbial colony indicated production of respective enzyme [19]. Xylanase activity was detected by flooding the plate with $0.4 \%$ Congo red dye and after 10 minutes washed with $1.0 \mathrm{M} \mathrm{NaCl}$. Formation of clear zone around growth indicated the production of xylanase [43]. 


\section{Results and discussion}

Microorganisms from marine environments as well as from spoiled foods, fruits, vegetables, etc. have been reported for production of extracellular hydrolyases. Some of these hydrolyases such as amylase, lipase, pectinase, protease, etc. have been commercially exploited. To the best of our knowledge this is the first report which describes screening of microbes isolated from Bhavnagar and Okhamadhi marine salterns for tyrosinase and tannase enzyme production.

\subsection{Screening of various hydrolytic extracellular enzymes}

In the present study Aspergillus versicolor, Xenoacremonium falcatum (PGF1) produced all the three enzymes namely, tannase, tyrosinase and xylanase. Bacillus licheniformis, Bacillus velezensis, Bacillus subtilis, BVUC_01 and BVUCh_02 produced tyrosinase and xylanase. Xenoacremonium falcatum(PGF4) and PGF2 produced tannase and xylanase. PGF3 produced tannase and tyrosinase. Bacillus megaterium and Salmonella typhi showed only tyrosinase activity. Only tannase activity was detected in Candida freyschussii tannase, while, Staphylococcus aureus did not produce any of these enzymes (Figure 1, 2 and 3; Table 1).

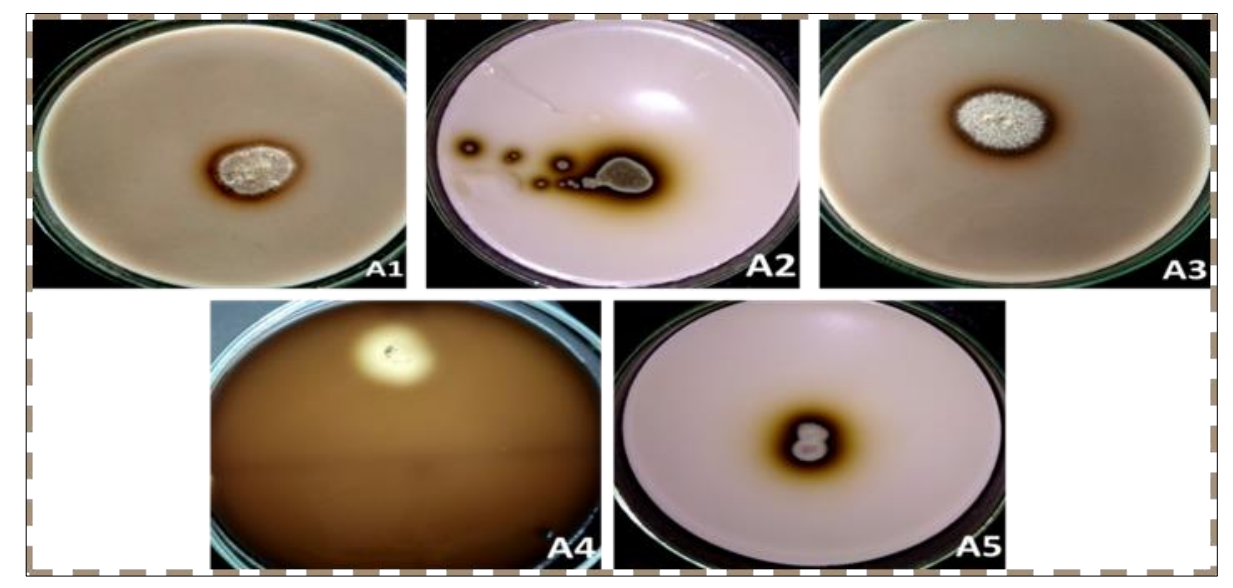

Figure 1 Results of screening of microorganisms for tannase production: A1, Xenoacremonium falcatum (PGF1); A2, PGF2; A3, Xenoacremonium falcatum (PGF4); A4, Candida freyschussii; A5, Aspergillus versicolor.

Table 1 Screening of cultures for tannase, tyrosinase and xylanase enzyme production

\begin{tabular}{|l|c|c|c|}
\hline Isolates & Tannase & Tyrosinase & Xylanase \\
\hline BVUC_01 & - & + & + \\
\hline Bacillus megaterium & - & + & - \\
\hline Bacillus licheniformis & - & + & + \\
\hline BVUCh_02 & - & + & + \\
\hline Aspergillus versicolor & + & + & + \\
\hline Bacillus velezensis & - & + & + \\
\hline Xenoacremoniumfalcatum(PGF1) & + & + & + \\
\hline PGF2 & + & - & + \\
\hline PGF3 & + & + & - \\
\hline Xenoacremoniumfalcatum(PGF4) & + & - & + \\
\hline Candida freyschussii & + & - & - \\
\hline Bacillus subtilis & - & + & + \\
\hline Pseudomonas aeruginosa & - & + & + \\
\hline Staphylococcus aureus & - & - & - \\
\hline Salmonella typhi & - & + & - \\
\hline
\end{tabular}


To the best of our knowledge this is the first report which shows production of tannase, tyrosinase, xylanase by Xenoacremonium falcatum and Candida freyschussii; tannase and tyrosinase by Aspergillus versicolor; and tyrosinase by Salmonella typhi.

These studied organisms also previously screened for production of various hydrolytic as well as therapeutic enzymes such as amylase, cellulase, chitinase, lipase, pectinase, protease, arginase, asparaginase, glutaminase [48, 49, 54]. These studies revealed that Aspergillus versicolor produced all the twelve (12) enzymes, while Bacillus velezensis showed all except, tannase activity. Bacillus velezensis, BVUC_01 and BVUCh_02 did not show pectinase and tannase activity [48, 54].
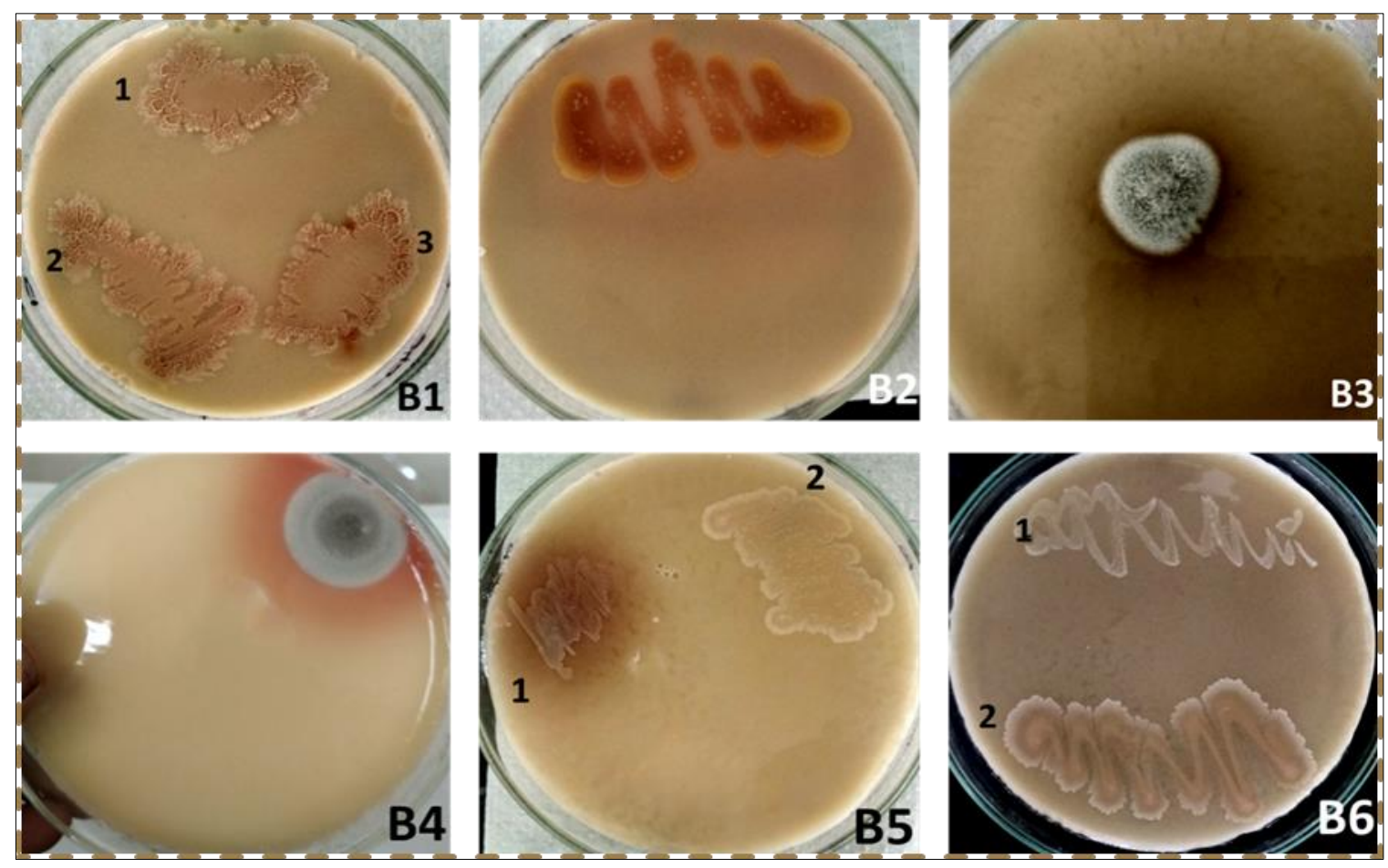

Figure 2 Results of screening for tyrosinase production; B1, (1-BVUCh_02, 2-Bacillus licheniformis, 3-BVUC_01); B2, (1Bacillus megaterium, 2-Bacillus subtilis); B3, Aspergillus versicolor; B4, Xenoacremonium falcatum(PGF1); B5, Salmonella typhi; B6, (1-Candida freyschussii, 2-Bacillus velezensis)

Lima et al. [55] used various species of Aspergillus and Penicillium for production of tannase from agro-industrial waste and leaves of Barbados cherry and mangaba fruit. They reported that $P$. montanense URM 6486 was the best producer of tannase using Barbados cherry residue as substrate. Many authors revealed that use of agro-industrial waste oil palm drastically increases tannase production [55, 56]. Mukesh et al. [57] isolated K. pneumoniae from soil and screened it for tannase production and also optimized various parameters for its production. Production of tannase from bacteria provides additional advantages such as rapid growth, ease of handling and short incubation period. The common genera reported for tannase production are Bacillus [58, 59, 60]; Lactobacillus [60], Pseudomonas [61], Staphylococcus [62], Klebsiella [58, 63], etc. Among microorganism fungi are widely used for research, industrial production as well as applications of tannase. The most commonly reported fungal genera for tannase production are Aspergillus[64, 65], Penicillium [64, 66] and Trichoderma [67]. Tannase production has also been reported in the yeast Candida sp..Saxena et al. [68] reported tannase production from Candida guilermondii and Candida tropicales. Yu et al. [69] and Albertse [70] studied recombinant yeast Pichia pastoris and Saccharomyces cerevisiae, respectively for tannase production. Farag et al. [71] isolated Aspergillus nomius GWA 5 from marine sediment of Western Harbour, Alexandria, Egypt and found that it had great ability to produce tannase that that can be active in wide range of $\mathrm{pH}$ and temperature suitable for industrial and pharmaceutical purpose.

Roy et al. [72] isolated marine actinobacteria from Marina beach $\left(13.05^{\circ} \mathrm{N}, 80.28^{\circ} \mathrm{E}\right)$, Chennai, Tamil Nadu, India and identified it as Streptomyces espinosus strain LK4. It produced tyrosinase which was stable at high temperature and $\mathrm{pH}$, and greater stability as well as yield than mushroom tyrosinase. They also found that the purified tyrosinase had great potential for the removal of phenol from aqueous solution. Immobilization of tyrosinase improved its thermal stability, protected it from proteolysis, increased efficiency of reusability, stability and viability [73-76]. Some fungi reported for 
tyrosinase production include Agaricus bisporus [77], Neurospora crassa [78, 79], Amanita muscaria [80], Aspergillus oryzae [81], Portabella mushrooms, Pycnoporus sanguineus [82], and Lentinula boryana [83, 84]. Bacterial tyrosinase is generally exploited for melanin production. The most common bacterial genera reported for tyrosinase production are Rhizobium, Symbiobacterium, Pseudomonas, Marinomonas, Thermomicrobium, Bacillus, Streptomyces [84 - 88]. Among these tyrosinases from Streptomyces spp. Are widely studied and characterized [84].During production of tyrosinase incubation in dark condition showed high enzyme activity, but the preferable condition for incubation is in light because it inhibits laccase production which is largely produced in dark condition [89,90]. Zaidi et al. [91] attempted extraction, purification and characterization of mushroom tyrosinase and found that it remained active at $30-65^{\circ} \mathrm{C}$ temperature and at neutral to slight acidic $\mathrm{pH}$. Mushroom tyrosinase showed high similarities with human tyrosinase, therefore can be a potential source of this enzyme for therapeutic use in melanogenesis.

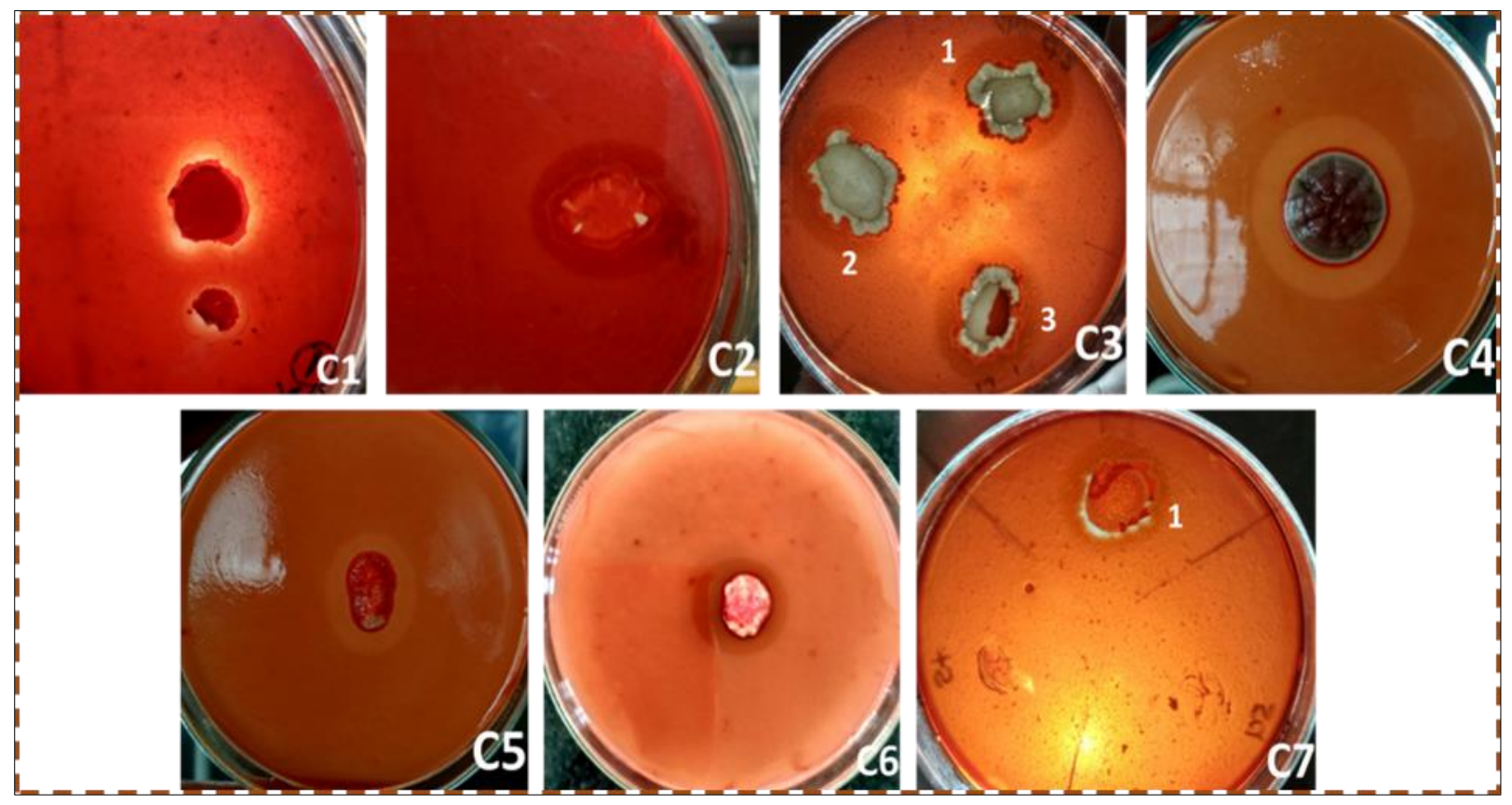

Figure 3 Results of screening of isolates for xylanase production; C1, Bacillus velezensis; C2, Bacillus subtilis; C3, (1BVUCh_02, 2-BVUC_01, 3-Bacillus licheniformis); C4, PGF2; C5, Xenoacremonium falcatum (PGF4); C6, Aspergillus versicolor; C7, Pseudomonas aeruginosa

Tannase has applications in various industries such as foods, animal feeds, cosmetic, pharmaceutical, chemical, leather industries, etc. [11, 53, 92, 93]. Tannase is used in food and pharmaceutical application which includes, in the manufacture of instant tea, stabilization of malt polyphenols, clarification of beer and fruit juices [94]. Tyrosinase is used in amalgam-biosensors for the detection of inconsequential level of volatile phenolics [95]. Xylanase plays a crucial role in pulp and paper industry. It has various roles in bioprocessing of fabrics, bioleaching of pulp, waste water recycling and bioconversion of various valuable products, food and feed $[42,45,96]$.

To the best of our knowledge this is the first report which describes screening of microorganisms isolated from Bhavnagar and Okhamadhi marine salterns for tyrosinase and tannase enzyme production. Further, research work on optimization for production and applications is envisaged.

\section{Conclusion}

A variety of hydrolyases is produced by the microorganisms isolated from marine salterns (Bhavnagar and Okhamadhi) as well as spoilt pomegranate. On the basis of the results, it can be concluded that tannase is produced by Aspergillus versicolor, Xenoacremonium falcatum (PGF1 and PGF4), PGF2, PGF3 and Candida freyschussii. All the organisms screened except PGF2, Xenoacremonium falcatum (PGF4), Candida freyschussii and Staphylococcus aureus produced tyrosinase. Xylanase activity was detected in most organisms, except Bacillus megaterium, PGF3, Staphylococcus aureus and Salmonella typhi. Further studies can be helpful for commercial exploitation of these isolates. 


\section{Compliance with ethical standards}

\section{Acknowledgments}

Authors acknowledge support from UGC-CPE grants for skill development. The facilities provided by the Principal, M. G. Science Institute and Ahmedabad Education Society (AES) management are gratefully acknowledged.

\section{Disclosure of conflict of interest}

Authors not have any conflict of interest.

\section{References}

[1] Pradeep K, Sharma SM. Enzymes in green chemistry: The need for environment and sustainability. International Journal of Applied Research. 2016; 2(6): 337-341.

[2] Agata T, Bartosz K, Krystian K, Walery Z. Enzymes - important players in green chemistry. Journal of Education, Health and Sport. 2017; 7(9): 217-223.

[3] Belur PD, Mugeraya G. Microbial production of tannase: State of the art. Research Journal of Microbiology. 2011; 6(1): 25-40.

[4] Dhruvil B, Modi HA, Jain NK. Preliminary isolation and screening of tannase producing bacteria and fungi. International Journal of Current Microbiology and Applied Science. 2014; 3(11): 193-203.

[5] Girdhari SN, Peshwe SA. Isolation and Screening of Tannase producing fungi. International Journal of Current Microbiology and Applied Science. 2015; 4(7): 765-774.

[6] Bhat TK, Singh B, Sharma OP. Microbial degradation of tannins - A current perspective. Biodegradation. 1998; 25 : 343-357.

[7] Hamada A Malak El, El-Banna A. Screening of Tannase Producing fungi isolated from tannin-rich sources. International Journal of Agricultural and Food Research. 2013; 2(3): 1-12.

[8] Zhang YN, Yin JF, Chen JX, Du QZ, Jiang YW, Xu YQ. Improving the sweet aftertaste of green tea infusion with tannase. Food Chemistry. 2016; 192: 470-476.

[9] Yu X, Li Y, Wang C, Wand D. Immobilization of Aspergillus niger tannase by microencapsulation and its kinetic characterization. Biotechnology and applied Biochemistry. 2004; 40: 151-155.

[10] $\mathrm{Yu} \mathrm{X,} \mathrm{Li} \mathrm{Y.} \mathrm{Kinetics} \mathrm{and} \mathrm{thermodynamics} \mathrm{of} \mathrm{synthesis} \mathrm{of} \mathrm{propyl} \mathrm{gallate} \mathrm{by} \mathrm{mycelium-bound} \mathrm{tannase}$ from Aspergillusniger in organic solvent. Journal of Molecular Catalysis B: Enzymatic. 2006; 40: 44-50.

[11] Aguilar CN, Gutierrez-Sanche G. Review: Sources, Properties, Applications and Potential uses of Tannin Acyl Hydrolase. Food Science and Technology International. 2001; 7(5): 373-82.

[12] Cavalcanti R, Ornela P, Jorge J, Guimarães LH. Screening, selection and optimization of the culture conditions for tannase production by endophytic fungi isolated from Caatinga. Journal of Applied Biology and Biotechnology. 2017; 5(01): 001-009.

[13] Pourrat H, Regerat F, Morvan P, Pourrat A. Microbiological production of gallic acid from Rhuscoriaria L. Biotechnology Letters. 1987; 9: 731-734.

[14] Archana DT, Kajal S, Lakshmi B. Study on tannase producing Bacillus megaterium isolated from tannery effluent. International Journal of Advanced Research in Biological Science. 2016; 3(7): 28-35.

[15] Aissam H, Errachidi F, Penninckx MJ, Merzouki M, Benlemlih M. Production of tannase by Aspergillus niger HA37 growing on tannic acid and olive mill waste waters. World Journal of Microbiology and Biotechnology. 2005; 21: 609-614.

[16] Himani O, Dimple P, Vikram R, Rakeshkumar P, Kiransinh R. Screening and production of tannase using fungal isolates from soil. Bioscience Biotechnology Research Communication. 2020;13(1): 73-77.

[17] Patil DB, Das SK, Das Mohapatra PK, Nag A. Physicochemical studies and optimization of gallic acid production from the seed coat of Terminalia belerica Roxb. Annals of Microbiology. 2011; 61: 649-654. 
[18] Arijit J, Chiranjit M, Suman Kumar H, Bikas RP, Keshab CM, Pradeep Kumar DM. Rapid screening of tannase producing microbes by using natural tannin. Brazilian Journal of Microbiology. 2012; 1080-1083.

[19] Olubusola AO, Adebosola 0, John OU. Optimization and characterization of tyrosinases from multi enzyme producing Fusarium solani and Fumago sp. Periodica Polytechnica Chemical Engineering. 2019; 63(4): 582-590.

[20] Robb DA. “Tyrosinase,” in Copper Proteins and Copper Enzymes, R. Lontie, Ed., pp. 207-241, CRC Press, Boca Raton, Fla, USA, 1984.

[21] Whitaker JR. "Polyphenol oxidase," in Food Enzymes: Structure and Mechanism, D.W. S. Wong, Ed., pp. 271-307, Chapman and Hall, New York, NY, USA.1995.

[22] Kamal U, Ayesha SA, Sharique AA, Ishrat N. Microbial Tyrosinases: Promising enzymes for pharmaceutical, food bioprocessing, and environmental industry. Biochemistry Research International, 2014; 854687: 16.

[23] Hamann JN, Herzigkeit B, Jurgeleit R, Tuczek F. Small-molecule models of tyrosinase: from ligand hydroxylation to catalytic monooxygenation of external substrates. Coordination Chemistry Reviews. 2017; 334: 54-66.

[24] Kurahashi Y, Pontzen R. Carpropamid: A new melanin biosynthesis inhibitor. Pfanzenschutz-Nachrichten Bayer. 1998; 51: 245-256.

[25] Soler-Rivas C, Jolivet S, Arpin N, Olivier JM, Wihers HJ. Biochemical and physiological aspects of brown blotch disease of Agaricus bisporus. FEMS Microbiol Review. 1999; 23: 591-614.

[26] Soler-Rivas C, Arpin N, Olivier JM, Wichers HJ. Activation of tyrosinase in Agaricus bisporus strains following infection by Pseudomonas tolaasii or treatment with a tolaasin-containing preparation. Mycological Research. 1997; 101: 375-382.

[27] Jacobson ES. Pathogenic roles for fungal melanins. Clinical Microbiology Review. 2000; 13: 708-717.

[28] Mayer AM, Harel E. Polyphenol oxidases in plants. Phytochemisty. 1979; 31: 193-215.

[29] Bell AA, Wheeler MH. Biosynthesis and functions of fungal melanins. Annual Review of Phytopathology. 1986; 24: 411-451.

[30] Halaouli S, Asther M, Sigoillot JC, Hamdi M, Lomascolo A. Fungal tyrosinases: new prospects in molecular characteristics, bioengineering and biotechnological Applications. Journal of Applied Microbiology. 2006; 100:219-232.

[31] Danial NE, Al-Bishri WM. Optimization of medium composition for increased production of tyrosinase enzyme in recombinant Bacillus megaterium. Research Journal of Pharmaceutical, Biological and Chemical Science. 2018; $9(1): 480-486$.

[32] Decker H, Tuczek F. Tyrosinase/ catecholoxidase activity of hemocyanins: structural basis and molecular mechanism. Trends in Biochemical Science. 2000; 25(8):392-397.

[33] Elsayed EA, Danial EN. Isolation, Identification and medium optimization for tyrosinase production by a newly isolated Bacillus subtilis NA2 Strain. Journal of Applied Pharmaceutical Science. 2018; 8(09):93-101.

[34] Grady CPL Jr. Biodegradation of toxic organics: status and potential. Journal of Environmental Engineering. 1990; 116(5): 805-828.

[35] Ha SR, Vinitnantharat S, Ozaki H. Bioregeneration by mixed microorganisms of granular activated carbon loaded with a mixture of phenols. Biotechnology Letters.2000; 22(13): 1093-1096.

[36] Marino SM, Fogal S, Bisaglia M, Moro S, Scartabelli G, De Gioia L, Spada A, Monzani E, Casella L, Mammi S, Bubacco L. Investigation of Streptomyces antibioticus tyrosinase reactivity toward chlorophenols. Archives of Biochemistry and Biophysics. 2011; 505(1):67-67.

[37] Xu DY, Chen JY, Yang Z. Use of cross-linked tyrosinase aggregates as catalyst for synthesis of L-DOPA. Biochemical Engineering Journal. 2012; 63:88-94.

[38] Zaidi KU, Ali AS, Ali SA, Naaz I. Microbial tyrosinases: promising enzymes for pharmaceutical, food bioprocessing, and environmental industry. Biochemistry Research International, ID 854687, 2014.

[39] Malherbe S, Cloete TE. Lignocellulose biodegradation: fundamentals and applications: A review. Environmental Science and Biotechnology. 2003; 1:105-114.

[40] Adesina FC, Onilude AA. Isolation, identification and screening of xylanase and glucanase-producing microfungi from degrading wood in Nigeria. African Journal of Agricultural Research. 2013; 8(34):4414-4421. 
[41] Beg QK, Kapoor M, Mahajan L, Hoondal GS. Microbial xylanases and their industrial applications: a review. Applied Microbiology and Biotechnology. 2001; 56:326-338.

[42] Dhiman SS, Sharma J, Battan B. Industrial applications and future prospects of microbial xylanases: a review. BioResources. 2008; 3(4):1377-1402.

[43] Burlacu A, Cornea CP, Israel-Roaming F. Screening of Xylanase producing microorganisms. Research Journal of Agricultural Science. 2016; 48(2):8-15.

[44] Collins T, Gerday C, Feller G. Xylanases, xylanase families and extremophilic xylanases. Microbiological Reviews. 2005; 29:3-23.

[45] Techapun C, Poosaran N, Wantanabe M, Sasaki K. Thermostable and alkaline tolerant microbial cellulase free xylanases produced from agricultural wastes and the properties required for use in pulp bleaching bioprocess: A Review. Process Biochemistry. 2003; 38:1327-1340.

[46] Shanthi V, Roymon MG. Isolation and screening of alkaline thermostable xylanase producing bacteria from soil in Bhilai Durg region of Chhattisgarh, India. International Journal of Current Microbiology and Applied Science. 2014; 3(8):303-311.

[47] Sakthivel M, Karthikeyan N, Jayaveny R, Palani P. Optimization of culture conditions for the production of extracellular cellulase from Corynebacterium lipophiloflavum. Journal of Ectobiotechnology. 2010; 2(9):06-13.

[48] Fenil AP, Jay NP, Vivek NU. Exploring microbes from Bhavnagar and Okhamadhi marine salterns for production of industrially important enzymes. International Journal of Innovative Research in Science, Engineering and Technology. 2021; 10(5):5391-5398.

[49] Jay NP, Fenil AP, Vivek NU. Isolation and characterization of pathogens causing disease in pomegranate (Punica granatum L.), India. International Journal of Innovative Research in Science, Engineering and Technology. 2021; 10(5):4403-4409.

[50] Pinto GAS, Leite SGF, Terzi SC, Couri S. Selection of tannase-producing Aspergillus niger strains. Brazilian Journal of Microbiology. 2001; 32:24-26.

[51] Raval KM, Vaswani PS, Majumder DR. Biotransformation of a single amino acid L-tyrosine into a bioactive molecule L-DOPA. International Journal of Scientific Research. 2012; 2(5):1-9.

[52] Mahilrajan S, Balakumar S, Arasaratnam V. Screening and identification of a thermophilic and alkalophilic bacterium producing xylanase. Advances in Applied Science Research. 2012; 3(1):242-250.

[53] Aguilar CN, Rodriguez R, Gutiérrez-Sanchez G, Augur C. Favela-Torres E, Prado Barragan L, Ramirez-Coronel A, and Contreras-Esquivel JC. Microbial tannases: advances and perspectives. Applied Microbiology and Biotechnology. 2007; 76:47-59.

[54] Fenil P, Jay P, Vivek U. Screening of microorganisms for production of therapeutic enzymes. European Journal of Biotechnology and Bioscience. 2021; 9(3):82-88.

[55] LimaJ, Cruz R, Fonseca J, Medeiros E, Cavalcanti Maciel M, Moreira K, Souza-Motta C. Production, characterization of tannase from Penicillium montanense URM 6286 under SSF using agroindustrial wastes, and application in the clarification of grape juice (Vitis vinifera L.). The Scientific World Journal. 2014.

[56] Sabu A, Pandey A, Jaafar Daud M, Szakacs G. Tamarind seed powder and palm kernel cake: two novel agro residues for the production of tannase under solid state fermentation by Aspergillus niger ATCC 16620. Bioresource Technology. 2005; 96(11):1223-1228.

[57] Mukesh K, Rana S, Beniwal V, Salar R. Optimization of tannase production by a novel Klebsiella pneumoniae KP715242 using central composite design. Biotechnology Reports. 2015; 7:128-134.

[58] Aboubakr Hamada. Isolation and screening of tannase- producing fungi and optimizing the enzyme production by the promising isolate. 2010 .

[59] Mondal KC, Banerjee D, Banerjee R, Pati BR. Production and characterization of tannase from Bacillus cereus KBR9. The Journal of General and Applied Microbiology.2001; 47:263-267.

[60] Nishitani Y, Osawa R. A novel colorimetric method to quantify tannase; activity of viable bacteria. Journal of Microbiological Methods. 2003; 54:281-284. 
[61] Selwal MK, Yadav A, Selwal KK, Aggarwal NK, Gupta R, Gautam SK. Optimization of cultural conditions for tannase production by Pseudomonas aeruginosa IIIB 8914 under submerged fermentation. World Journal of Microbiology and Biotechnology. 2010; 26:599-605.

[62] Noguchi N, Ohashi T, Shiratori T, Narui K, Hagiwara T, Ko M, Watanabe K, Miyahara T, Taira S, Moriyasu F, SasatsuM. Association of tannase-producing Staphylococcus lugdunensis with colon cancer and characterization of a novel tannase gene. Journal of Gastroenterology. 2007; 42:346-351.

[63] Franco AR, Calheiros CSC, Pacheco CC, Marco P, Manaia CM, Castro PML. Isolation and characterization of polymeric galloyl-ester degrading bacteria from a tannery discharge place. Microbial Ecology. 2005; 50:550-556.

[64] Rajakumar GS, Nandy SC. Isolation, purification, and some properties of Penicillium chrysogenum tannase. Applied and Environmental Microbiology. 1983; 46:525-527.

[65] Paranthaman R, Vidyalakshmi R, Murugesh V, Singaravadivel K. Optimization of various culture media for tannase production in submerged fermentation by Aspergillus flavus. Advances in Biological Research. 2009; 3:34-39.

[66] Raaman N, Mahendran B, Jaganathan C, Sukumar S, Chandrasekaran V. Optimisation of extracellular tannase production from Paecilomyces variotii.World Journal of Microbiology and Biotechnology. 2010; 26:1033-1039.

[67] Bajpai B, Patil S. Induction of tannin acyl hydrolase (EC 3.1.1.20) activity in some members of fungi imperfecti. Microbial Technology. 1997; 20:612-614.

[68] Saxena S, Saxena RK. Statistical optimization of tannase production from Penicillium variable using fruits (Chebulic myrobalan) of Terminalia chebula. Biotechnology and Applied Biochemistry. 2004; 39:99-106.

[69] Yu XW, Li YQ. Expression of Aspergillus oryzae tannase in Pichia pastoris and its application in the synthesis of propyl gallate in organic solvent. Food Technology and Biotechnology. 2008; 46:80-85.

[70] Albertse EH. Cloning, expression and characterization of tannase from Aspergillus Species [M.Sc. Thesis]. Faculty of Natural and Agricultural Sciences, University of the Free State,South Africa. 2002.

[71] Farag A, Hassan S, Elsayis A, Ghanem K. Purification, characterization and application of Tannase enzyme isolated from marine Aspergillus nomius GWA5. Journal of Pure and Applied Microbiology. 2018; 12:1939-1949.

[72] Roy S, Das I, Munjal M, Loganathan K, Kumar G, Kumar S, Venkata K, Rao B. Isolation and characterization of tyrosinase produced by marine actinobacteria and its application in the removal of phenol from aqueous environment. Frontiers of biology. 2014; 9(4).

[73] Bevilaqua J, Cammarota M, Freire D, SantAnna GL. Phenol removal through combined biological and enzymatic treatments. Brazilian Journal of Chemical Engineering. 2002; 19(2).

[74] Molina LP, Hiner ANP, Tudela J, Garcı'a-Ca'novas F, Rodrı'guez- Lo'pez JN. Enzymatic removal of phenols from aqueous solution by artichoke (Cynarasco lymus L.) extracts. Enzymes in Microbial Technology. 2003; 33(5):738742 .

[75] Kameda E, Langone MA, Coelho MA. Tyrosinase extract from Agaricus bisporus mushroom and it's in natura tissue for specific phenol removal. Environmental Technology. 2006; 27(11):1209-1215.

[76] Crecchio C, Ruggiero P, Pizzigallo MDR. Polyphenol oxidases immobilized in organic gels: Properties and applications in the detoxification of aromatic compounds. Biotechnology and Bioengineering. 1995; 48(6):585591.

[77] Strothkamp KG, Jolley RL, Mason HS. Quaternary structure of mushroom tyrosinase. Biochemical and Biophysical Research Communications. 1976; 70(2):519-524.

[78] Lerch K. Copper monooxygenases: tyrosinase and dopamine B-monooxygenase," in Metal Ions in Biological Systems, H. Sigel, Ed., Marcel Dekker, New York, NY, USA. 1983; 143-186.

[79] Lerch K. Neurospora tyrosinase: structural, spectroscopic and catalytic properties. Molecular and Cellular Biochemistry. 1983; 52(2):125-138.

[80] Mueller LA, Hinz U, Zryd JP. Characterization of a tyrosinase from Amanita muscaria involved in betalain biosynthesis. Phytochemistry. 1996; 42(6):1511-1515.

[81] Nakamura M, Nakajima T, Ohba Y, Yamauchi S, Lee BR, Ichishima E. Identification of copper ligands in Aspergillus oryzae tyrosinase by site-directed mutagenesis. Biochemical Journal. 2000; 350(2):537-545. 
[82] Halaouli S, Asther M, Kruus K et al. Characterization of a new tyrosinase from Pycnoporus species with high potential for food technological applications. Journal of Applied Microbiology. 2005; 98(2):332-343.

[83] De Faria RO, Moure VR, Balmant W, Amazonas MALDA, Krieger N, Mitchell DA. The tyrosinase produced by Lentinula boryana (Berk. \& Mont.) pegler suffers substrate inhibition by l-DOPA. Food Technology and Biotechnology.2007; 45(3):334-340.

[84] Zaidi KU, Ali AS, Ali SA, Naaz I. Microbial tyrosinases: promising enzymes for pharmaceutical, food bioprocessing, and environmental industry. Biochemistry Research International, ID 854687, 2014.

[85] Liu Z, Liu Y, Yang H, Yang Y, Shen G, Yu R. A phenol biosensor based on immobilizing tyrosinase to modified coreshell magnetic nanoparticles supported at a carbon paste electrode. Analytica Chimica Acta. 2005; 533(1):39.

[86] Claus H, Decker H. Bacterial tyrosinases. Systematic and Applied Microbiology. 2006; 29(1):3-14.

[87] McMahon AM,Doyle EA, Brooks S, O'Connor KE. Biochemical characterisation of the coexisting tyrosinase and laccase in the soil bacterium Pseudomonas putida F6.Enzyme and Microbial Technology. 2007; 40(5):1435-1441.

[88] Matoba Y, Kumagai T, Yamamoto A, Yoshitsu H, Sugiyama M. Crystallographic evidence that the dinuclear copper center of tyrosinase is flexible during catalysis. The Journal of Biological Chemistry. 2006; 281(13):8981-8990.

[89] Duarte L, Tiba J, Santiago M, Garcia T, Bara M. Production and characterization of tyrosinase activity in Pycnoporus sanguineus CCT-4518 Crude extract. Brazilian journal of microbiology: [publication of the Brazilian Society for Microbiology]. 2012; 43(1): 21-9.

[90] Garcia TA, Santiago MF, Ulhoa CJ. Properties of laccases produced by Pycnoporus sanguineus induced by 2,5xylidine. Biotechnology Letters. 2006; 28:633-636.

[91] Zaidi K,Ali A, Ali S. Purification and characterization of melanogenic enzyme tyrosinase from Button Mushroom. Enzyme research. 2014; (2).

[92] Dũenas M, Hernandez T, Estrella I. Changes in the content of bioactive polyphenolic compounds of lentils by the action of exogenous enzymes: Effect on their antioxidant activity. Food Chemistry. 2007; 101:90-97.

[93] Jun C, Yoo M, Lee W, Kwak K, Bae M, Hwang W, Son D, Chai K. Ester derivatives from tannase-treated prunioside and their anti-inflammatory activities. Bulletin of the Korean Chemical Society. 2007; 28:73-76.

[94] Cantarelli C, Brenna O, Giovanelli G, Rossi M. Beverage stabilization through enzymic removal phenolics. Food Biotechnology. 1996; 3:203-213.

[95] Fang Y, Ramasamy RP. Detection of p-ethylphenol, a major plant volatile organic compound, by tyrosinase-based electrochemical biosensor. ECS Journal of Solid State Science and Technology. 2016; 5(8): 3054-3059.

[96] Haki GD, Rakshit SK. Developments in industrially important thermostable enzymes: a review. Bioresource Technology. 2003; 89:17-34. 